\title{
9 Women-headed households, migration and adaptation to climate change in the Mahanadi Delta, India ${ }^{1}$
}

\author{
Sugata Hazra, Amrita Patel, Shouvik Das, \\ Asha Hans, Amit Ghosh, and Jasmine Giri
}

\section{Introduction}

Given the socially determined roles of men and women, contemporary gendered research on the social impacts of climate change enables a better understanding of their differential vulnerabilities, coping mechanisms and adaptation processes. This chapter focuses on women-headed households in relation to vulnerability, migration and adaptation in the context of climate change in the Mahanadi Delta (MD) in India, which comprises five coastal districts in the state of Odisha: Bhadrak, Kendrapara, Jagatsinghpur, Puri and Khordha.

Recent research has contributed to analyzing the impact of climate variability in the identified geographical locations where gendered household differentials are observed as a consequence of their adaptive capacities and sensitivity (IPCC 2014; Kuppannan et al. 2015; Solomon and Rao 2018). A systemic disadvantage is reflected in both policy and research where women's vulnerability is seen to pose obstacles to their wellbeing and very survival in climate change situations (Alhassan et al. 2019; Morchain et al. 2015; Singh 2019). In this situation the biggest challenge is gendered loss of livelihood and food security forcing people to migrate (Afifi et al. 2016; Duncan et al. 2017; Rao and Mitra 2013).

Investigation of households in migrant situations from a gendered perspective has been limited, and though it is increasing - albeit with a variety

1 The authors thank DECCMA-India team members who provided insight and expertise that was immensely helpful for the research.

This work is carried out under the Deltas, Vulnerability and Climate Change: Migration and Adaptation (DECCMA) project (IDRC 107642) under the Collaborative Adaptation Research Initiative in Africa and Asia (CARIAA) programme with financial support from the UK Government's Department for international Development (DfID) and the International Development Research Centre (IDRC), Canada. The views expressed in this work are those of the creators and do not necessarily represent those of DfID and IDRC or its Board of Governors. 
of conflicting assumptions and conclusions - the overall understanding at inter- and intra-household levels is limited to a few authors (Desai and Banerji 2008; Pottier 1994). It is pertinent to recognize that the issue of headship is often addressed with a lack of clear methodology. In most of the research on gender and climate change, women and men are seen in binary terms and treated as undifferentiated homogeneous entities. Several authors highlight the multidimensionality of gender relationships and how they are shaped by various intersectionalities, such as of caste, class, social status or age, while others have investigated gender disparity within households, where women-headed households are found to be more vulnerable due to gaps in income and in access to social and economic resources (Mitra 2018; Rao and Hans 2018; Williams 2015). Recently a new line of thought considering male vulnerability and poverty as important areas for investigation has emerged (Chant 2003; Chant 2015; Nabikolo et al. 2012; Oginni et al. 2013). These different positions nevertheless illustrate that gender disparities and disadvantages specific to women-headed households combine to make them economically vulnerable in general, and more so in the context of climate shocks.

The limitation in existing research on migration and climate change is that while impact on men- and women-headed households is examined, there exists no analysis of women-headed households with and without migrants as a separate category, based on an extensive database. The other omission has been in the context of adaptation, where there has been no analytical space for the success of adaptation strategies. In this analyses, the suggested gender of the head of the household is not merely a reference point as it does have significant socio-economic impact implications (Gangopadhyay and Wadhwa 2004). First, women-headed households, as illustrated in existing literature, may have more dependents and thus have lower worker/non-worker ratios than other households (Klasen et al. 2015). Second, due to gender biases, women heads might have to work for low wages and have less access to assets and productive resources, such as land, financial capital and technology, than men, threatening the wellbeing of the household (Agarwal 1994; Alhassan et al. 2019). Third, women typically bear the burden of household chores and look after children and dependents without other support, resulting in time and mobility constraints, unlike in men-headed households (Buvinić and Gupta 1997; Rosenhouse 1989). Overall, women-headed households seem poorer than men-headed households (Gangopadhyay and Wadhwa 2004; Unisa and Datta 2005).

Data remain an important indicator of the gendered complexity from different levels. The Census of India categorizes the head of household by marital status: 'never married', 'currently married', 'widowed', 'divorced' and 'separated'. The definition of the head of household for census purposes is a person who is recognized as such by the household. ${ }^{1}$ According to the Census, the number of women-headed households in the country 


\section{Sugata Hazra et al.}

is increasing. Between 2001 and 2011, women-headed households rose from 10.4 per cent to 13.2 per cent of total households. In Odisha, the proportion of women-headed households also increased from 10.1 per cent to 12.5 per cent of total households during the same period. ${ }^{2}$ Among the women household heads, widows comprise 68.3 per cent and 64.5 per cent nationally and in the state of Odisha, respectively. In the delta districts, the proportion of women-headed households increased from 9.4 per cent to 12 per cent between 2001 and 2011, registering a growth rate of 6 per cent annually (from 0.13 million in 2001 to 0.21 million in 2011). Widows in the five delta districts average 57.6 per cent and 56.6 per cent respectively in the 2001 and 2011 Censuses. The National Family Health Survey (NFHS) data also show an increase in women-headed households: ${ }^{3} 9.2$ per cent, 10.3 per cent and 14.4 per cent in NFHS I (1992-93), II (1998-99) and III (2005-06) respectively (Kumar and Gupta 2012).

A majority ( 78.8 per cent) of the 23 million women-headed households $^{4}$ (12.8 per cent of total households) surveyed in rural India in the Socio-Economic Caste Census (SECC), had a monthly income less than Rs. 5,000 (Government of India SECC 2011a, b). Overall, 14 million women-headed households are 'deprived' according to the SECC, where deprivation criteria are based on conditions of housing, landlessness, absence of an able-bodied adult member, any adult male member or a literate adult (Maqsoodi 2015). Poverty is affected by gender and the choice of poverty measures does not influence the results (Julka and Das 2015). However, despite the poverty (Nagla 2008), it is argued that women in women-headed households successfully network to gain information and support, which suggests higher confidence and decision-making powers, factors that play an important role in adaptation processes. In the climate-change policy framework of India, the National Action Plan (NAPCC) recognizes that the impacts of climate change could prove particularly severe for women. Women-headed households, however, are not mentioned and all women are projected as a homogeneous category, undifferentiated by caste, class, age, marital status or region (Government of India 2008). ${ }^{5}$

This chapter begins with an introduction on climate change and women-headed households. The second section provides the administrative, demographic and socio-economic characteristics of the study area. The third section establishes the link between environmental risk and migration. The fourth section describes the data and the methodological approach of the household survey. The fifth section discusses the research findings on vulnerability, migration and adaptation activities of the women-headed households, and the final section concludes by highlighting the chapter's contributions to the literature as well as the implications of the findings for policy making. 


\section{The Mahanadi Delta}

The Mahanadi Delta (MD) comprises a network of three major rivers - the Mahanadi, the Brahmani and the Baitarini - draining into the Bay of Bengal, covering a coastline of $200 \mathrm{~km}$, and stretching from the south near Chilika, the largest coastal lagoon in Asia, up to the Dhamra river in the north. The study area under the Deltas, Vulnerability, Climate Change: Migration and Adaptation (DECCMA) ${ }^{6}$ project in the MD consists of 45 sub-districts (community development blocks) within the five coastal districts of Bhadrak, Kendrapara, Jagatsinghpur, Puri and Khordha (Figure 9.1), which is delineated based on the $5 \mathrm{~m}$ contour line and administrative boundaries (Lazar et al. 2015). With an area of $13,000 \mathrm{~km}^{2}$, it covers 8 per cent of Odisha's geographical area.

In 2011 the population of MD was 8 million, a population density much higher than that of Odisha (270 persons per $\left.\mathrm{km}^{2}\right)$ and India (382 persons per $\mathrm{km}^{2}$ ). Almost 78 per cent of the population is rural. They are mainly dependent on agriculture, working as cultivators and agricultural labourers.

As far as the situation of women is concerned, their work participation rate is low in general, which is important to note for the purpose of adaptation strategies and policy intervention. The gender gap is stark, as the male work participation rate of the five districts is high (55.4 per cent), whereas women's participation is only 12.3 per cent, much lower than the state average of 27.2 per cent (Government of India 2011a). The larger proportion of women workers are engaged in household industries both in rural and

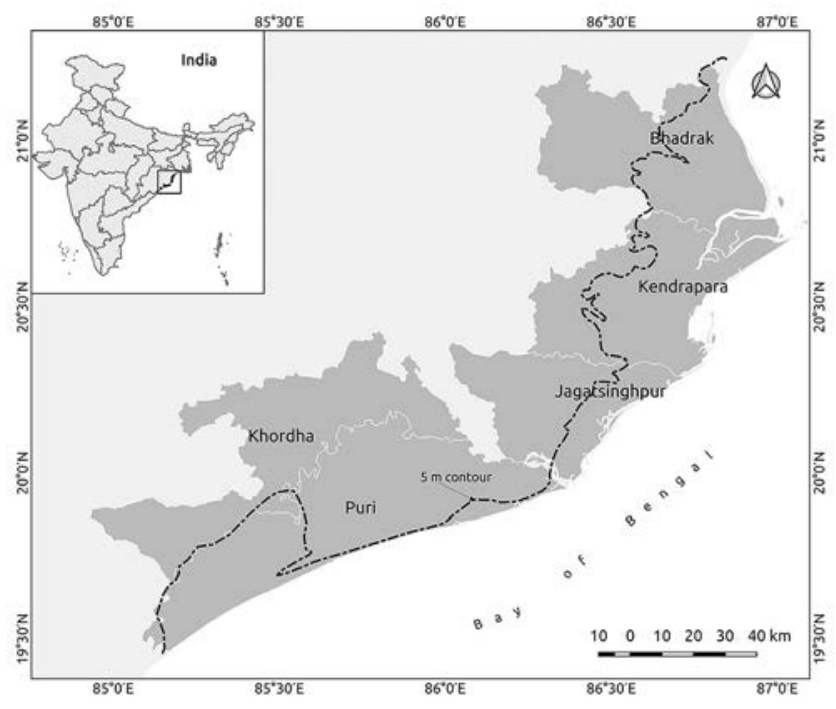

Figure 9.1 The study area map of Mahanadi Delta. 


\section{Sugata Hazra et al.}

urban areas. Employment generated in favour of women under Mahatma Gandhi National Rural Employment Guarantee Scheme (MGNREGS) in the MD is low (12.22lakh man-days) in comparison to districts with high tribal population like Mayurbhanj (22.16 lakh man-days). The number of self-help groups functioning with government support in delta districts is also low, being less than half that of non-delta districts like Ganjam and Mayurbhanj (Government of Odisha, 2014-15). This picture of women's low work participation in all fields and low productive engagement contrasts with women's literacy, ${ }^{7}$ which is high in the MD (about 80 per cent) (IIPS 2015-16).

Furthermore, the average proportion of women-headed households over the five delta districts is 12.5 per cent, but Kendrapara district has a high percentage of women-headed households ( 15.3 per cent), of whom 46.4 per cent are currently married. While the district of Puri has a high percentage (64 per cent) of widow-headed households, the four other delta districts have a lower percentage (55 per cent on average) (Government of India 2011a). Thus the status of women in the delta districts presents a complex picture with high literacy rates and low work participation of women, accompanied by the presence of a significant proportion of widows and married women heads in some districts. Currently married women-headed households indicate the absence of men who are most likely to be long-term migrants. This scenario merits a nuanced understanding not only of the gender dynamics but also of the heterogeneity of the women, specifically the women heads of households. This chapter seeks to analyze the social realities in the context of climate change through household survey results (Table 9.1).

\section{Coastal hazard and migration}

The MD is vulnerable to natural hazards like recurrent floods, high-intensity cyclones, storm surges and coastal erosion. All the coastal districts of Odisha were affected more than 10 times by cyclones and floods during 1995-2012 (Government of Odisha 2012-2013). The intensity of floods is severe during the cyclones, causing greater damage to the coastal districts (Bahinipati 2014). Severe floods in August 2011 devastated coastal Odisha. 877 villages were completely cut off from the rest of the state, and 528 hectares (ha) of agricultural land in Dhamnagar and Bhandari Pokhari areas were inundated due to high flood in the Baitarani river (Jata et al. 2011).

In the1999 'super-cyclone', 9,078 lives were lost, 445,595 houses collapsed, 13,762 houses were washed away and around 0.7 million hectares of agriculture were affected in the five deltaic districts alone (Government of Orissa 2004). After the super-cyclone, Odisha experienced several catastrophic tropical cyclones, including Phailin in 2013, Hudhud in 2014, Titli in 2018 and Fani in 2019. These cyclones adversely impacted people's livelihoods. Women, being at the centre of household management, were the worst sufferers (Iwasaki 2016; Patra et al. 2013; Swain et al. 2016). 
Table 9.1 Socio-economic profile of the five districts of the Mahanadi Delta

\begin{tabular}{|c|c|c|c|c|c|c|c|c|c|}
\hline & & Odisha & Bhadrak & Jagatsinghpur & Kendrapara & Khurdha & Puri & $\begin{array}{l}\text { Average } \\
\text { of } 5 \\
\text { districts }\end{array}$ & Source \\
\hline $\begin{array}{l}\text { Female literacy rate (for } \\
\text { population } 7 \text { yrs and } \\
\text { above) }\end{array}$ & & 64 & 75.8 & 80.6 & 79 & 81.6 & 78.3 & 79.1 & Census 2011 \\
\hline Work participation Rate & Male & 56.1 & 53.9 & 56.3 & 53.8 & 55.3 & 57.6 & 55.4 & Census 2011 \\
\hline Work participation Rate & Female & 27.2 & 7.9 & 14 & 11.1 & 13.5 & 14.8 & 12.3 & Census 2011 \\
\hline $\begin{array}{l}\text { Physical achievement } \\
\text { under NRLM in } \\
\text { 2013-14 }\end{array}$ & $\begin{array}{r}\text { Num of SHG } \\
\text { functioning }\end{array}$ & 271559 & 8404 & 10124 & 9922 & 11539 & 10273 & & $\begin{array}{l}\text { Economic } \\
\text { Survey } \\
\text { Odisha, } \\
2014-15\end{array}$ \\
\hline $\begin{array}{l}\text { Employment generation } \\
\text { under MGNEGS in } \\
\text { 2013-14- employment } \\
\text { generated in lakh } \\
\text { mandays }\end{array}$ & Women & 238.9 & 3.1 & 1.9 & 1.7 & 1.9 & 1.6 & & $\begin{array}{l}\text { Economic } \\
\text { Survey } \\
\text { Odisha, } \\
2014-15\end{array}$ \\
\hline $\begin{array}{l}\text { Women headed } \mathrm{HH} \text { as \% } \\
\text { of Total HH }\end{array}$ & & 12.5 & 11.5 & 12.2 & 15.3 & 11.2 & 10.3 & 12.1 & Census 2011 \\
\hline $\begin{array}{l}\text { Currently married Women } \\
\text { headed HHs as \% of } \\
\text { Total Female headed } \\
\text { HHs }\end{array}$ & & 26 & 34.3 & 35.5 & 46.4 & 34.1 & 28.5 & & Census 2011 \\
\hline $\begin{array}{l}\text { Widowed women headed } \\
\text { households }\end{array}$ & & & 57.4 & 57.2 & 47.8 & 56.7 & 64 & & Census 2011 \\
\hline
\end{tabular}




\section{Sugata Hazra et al.}

The main livelihood of this delta is agriculture and the majority of farmers are smallholders, who are exposed to frequent climate hazards and socio-economic stresses (Duncan et al. 2017).

Both fast-onset climatic hazards like cyclone, surge or flood and slow-onset hazards like sea-level rise, coastal land loss, heatwaves and droughts potentially displace large numbers of people from the coast globally (Doocy et al. 2013; Needhams et al. 2015; Rahman et al. 2015). Odisha is no exception. Migration, mostly internal, can be permanent or temporary. It is often difficult to assess the exact number of out-migrants from census data. Second, it is a difficult task to identify whether the out-migration is any way linked to propensity and risk of climatic hazards and variability.

In the present research under the DECCMA project, following the Intergovernmental Panel on Climate Change (IPCC) fifth assessment report (AR 5), risk and net migration have been analyzed using the indirect method and mapped at the sub-district level in MD to understand the link between migration and climate risk. According to IPCC AR 5, risk is the function of three factors: hazard (H), vulnerability (V) and exposure (Ex) (IPCC 2014). The term vulnerability has been split into 'sensitivity' and 'adaptive capacity' for the simplification of the conceptual and methodological frameworks of risk. Flood, cyclone and coastal erosion which are the common environmental stressors in MD are included in the hazard category of the risk assessment. Population density, agricultural dependency and road density are used as exposure, sensitivity and adaptive capacity, respectively, for the risk assessment. Net migration (the difference between in-migration and out-migration) has been estimated using the vital statistics method (indirect method), in the absence of data on place of birth, place of enumeration and age/sex-disaggregated data at the sub-district level. From the Geographical Information System (GIS) overlay analysis, a close correspondence of high-risk zones with negative net migration (more out-migration or sending areas) can be observed, while the low-risk zones in the delta mostly appear as net receiving areas with more in-migration (Figure 9.2).

Several sub-districts where out-migration dominates, such as Dhamnagar, Ersama, Balikuda and Tihidi, are bio-physically and socio-economically at very high risk (Das et al. 2016). Seasonal migration from these coastal districts results from the repeated crop loss and lack of returns from existing livelihoods (Das et al. 2016). While male migration dominates the trend, women's migration is picking up gradually from vulnerable parts of MD. Many women who have school education are now going to Puri or Bhubaneswar for work in small industries (Das et al. 2016; Samling et al. 2015). Movement of young girls, particularly those who are unmarried and have some skills, to garment industries in Bengaluru, Tiruppur and Chennai is also seen. ${ }^{8}$

Khordha, which is the most urbanized district in Odisha with 42.9 per cent urban population, Puri, a famous destination for religious tourism and Paradip, a growing sea port, have emerged as the preferred destination areas for migrants coming from adjoining rural communities of MD 


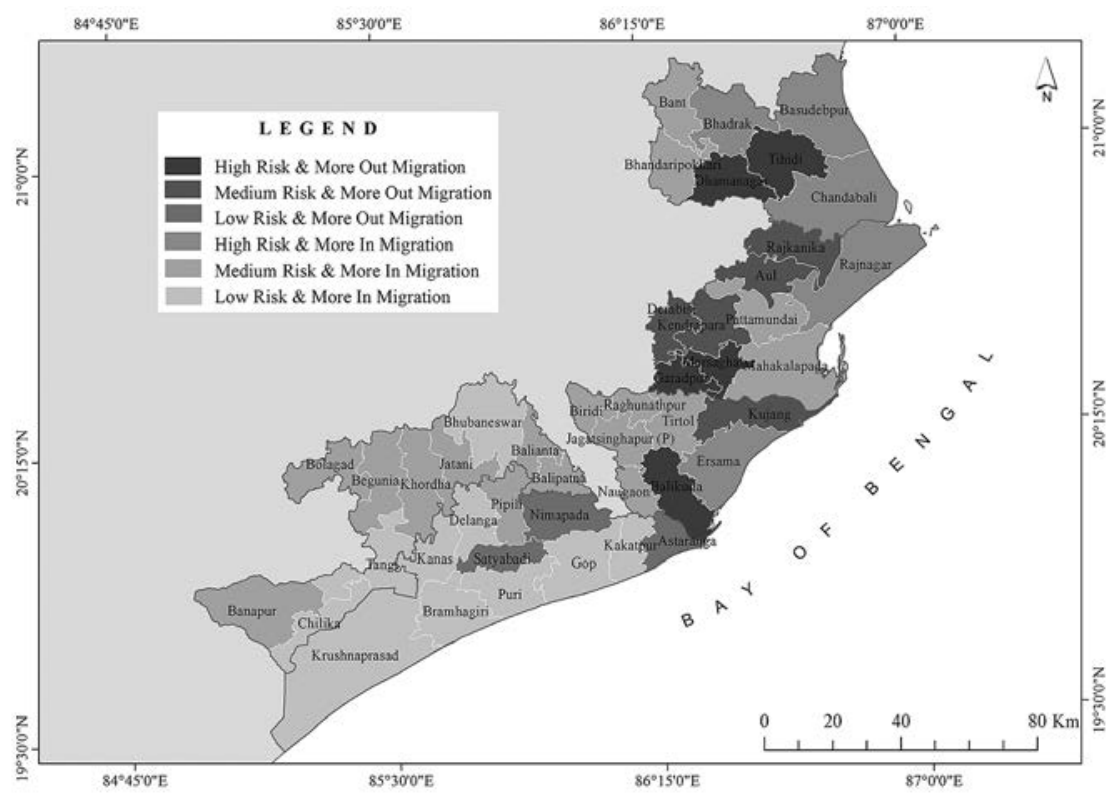

Figure 9.2 Multi hazard risk and migration map of Mahanadi Delta.

for greater economic opportunities. Migrants have also moved to Chennai, Gujarat, Tamil Nadu and Kerala (inter-state) and Qatar, Saudi Arabia and Dubai (international). Climate change can thus already be seen to be affecting people living in the region; the migration dynamics, specifically the out-migration of males and the emergence of women heads of households, are visible. Women living in rural areas are more dependent on natural resources and agriculture for their livelihood. It is therefore necessary to understand the complexity of links between the geo-physical, agro-ecological and socio-economic situations with regard to women, particularly for women left behind due to male migration, if workable policies for them are to be suggested.

Taking the lead from the secondary data analysis, an extensive household survey in the five coastal districts of MD was undertaken during 2016 for better understanding of the ground realities of migration, climatic hazard perception, vulnerabilities and scope of in-situ adaptation with a gendered perspective.

\section{Household survey: methodology and data analysis}

Fifty locations in the five Districts of the MD were identified by applying a two-stage cluster sampling technique for the implementation of the household survey. The first stage was a village-level multi-hazard map (flood, cyclone, erosion), which divided the MD (study area) into five multi-hazard zones (very low, low, medium, high and very high). In each of the zones, a 


\section{Sugata Hazra et al.}

number of locations (villages) were selected proportional to the number of households. In the second stage, 10,000 households were listed in the 50 identified locations (200 households in each location), based on demographic and migration characteristics, and from that, for the final survey 1500 households (30 in each location) were selected proportional to the number of migrant-sending households ${ }^{9}$ and non-migrant households ${ }^{10}$ as per the information collected during the household listing. Finally, 1414 households participated in the household survey, of which 22 per cent were migrant-sending households. The number of men- and women-headed households were 1225 (86.6 per cent) and 189 (13.4 per cent) respectively, ${ }^{11}$ In this chapter, we restrict our discussions to the status of the 189 women-headed households, 82 (43.3 per cent) of whom were migrant-sending households, while 107 (56.6 per cent) were households without any migrants. There is a high percentage of widows ( 60.32 per cent).

Several tables on socio-economic characteristics of respondents, patterns of migration from women-headed households and the status of adaptation activities in women-headed households were generated especially for this chapter using Statistical Package for the Social Sciences (SPSS) software.

\section{Women-headed households in the Mahanadi Delta}

The distribution of respondents for men- and women-headed households according to socio-economic characteristics is presented in Table 9.2. The social characteristics include household size, age, marital status, caste and formal education.

Among social characteristics, household size plays a significant role as it influences the income and expenditure of a household. Survey data show that average household size is 4.87 for men-headed households and 4.27 for women-headed households, and a smaller 3.46 for widow-headed households. Age is another important variable as it has a direct relationship with social and environmental awareness. Almost 32 per cent of the women heading a household are below the age of 40 . For both men and women heads of households, the highest percentage is found between the ages of 40 and 60 years; around 25 per cent of heads of households are over 60 years. Widows' vulnerability is revealed through age, with those aged 40 and above constituting 89 per cent.

Marital status plays a gendered role in the society. According to the survey of the 1414 households, more than 90 per cent of male household heads were currently married, but only 32.8 per cent of the women heads were, given the general restrictions on the remarriage of widows $(60.3$ per cent) (Chen 1998). Education is another significant variable associated with better economic and psychological outcomes. In keeping with the national trend of census data, the education level of male respondents was observed to be much higher than that of the female. Women respondents from women-headed households with no education (41.3 per cent) are greater in number than those with primary and secondary education in the sample. More 
Table 9.2 Socio-economic characteristics of respondents $(N=1414)$

\begin{tabular}{|c|c|c|c|c|}
\hline & aracteristics & Men Headed & Women & Widow \\
\hline Household & $1-3$ & 22.06 & 38.62 & 55.26 \\
\hline Size & $4-6$ & 63.73 & 51.32 & 37.72 \\
\hline & $\geq 7$ & 14.22 & 10.05 & 7.02 \\
\hline & Mean Household Size & 4.87 & 4.27 & 3.46 \\
\hline Age (Years) & $\leq 40$ & 26.2 & 31.75 & 13.16 \\
\hline & $41-60$ & 47.84 & 38.62 & 44.74 \\
\hline & $>60$ & 25.88 & 29.63 & 42.11 \\
\hline & Mean Age & 51.95 & 51.48 & 58.15 \\
\hline Marital Status & Never married & 1.8 & 1.59 & - \\
\hline & Currently married & 93.47 & 32.8 & - \\
\hline & Widowed & 4.57 & 60.32 & 100.00 \\
\hline & $\begin{array}{l}\text { Divorced/Abandoned / } \\
\text { separated }\end{array}$ & 0.08 & 5.29 & - \\
\hline Caste & General & 34.23 & 33.33 & 33.33 \\
\hline & Scheduled Caste (SC) & 24.35 & 20.63 & 21.93 \\
\hline & Scheduled Tribe (ST) & 1.8 & 2.65 & 3.51 \\
\hline & $\begin{array}{l}\text { Other backward caste } \\
\text { (OBC) }\end{array}$ & 39.62 & 43.39 & 41.23 \\
\hline Formal & No Education & 11.59 & 41.27 & 54.39 \\
\hline Education & Primary Education & 38.53 & 30.16 & 32.46 \\
\hline & Secondary Education & 36.16 & 23.81 & 10.53 \\
\hline & Higher Education & 13.63 & 4.76 & 2.63 \\
\hline Main & Farmer \& Fishermen & 36.08 & 5.29 & 6.14 \\
\hline Livelihood & $\begin{array}{l}\text { Regular Salaried } \\
\text { Employee }\end{array}$ & 8.57 & 5.29 & 3.51 \\
\hline & Small Business Owner & 7.84 & 4.76 & 3.51 \\
\hline & $\begin{array}{l}\text { Construction \& } \\
\text { Factory Workers }\end{array}$ & 21.55 & 4.76 & 2.63 \\
\hline & Unpaid Home Carer & 0.82 & 36.51 & 20.18 \\
\hline & $\begin{array}{l}\text { Others (Retired, } \\
\text { Pension holder, } \\
\text { Supported by } \\
\text { Relatives/Family, } \\
\text { Unemployed, etc.) }\end{array}$ & 25.06 & 43.39 & 64.04 \\
\hline Monthly & No Income & 3.43 & 36.51 & 18.42 \\
\hline Income & $\leq 3000$ & 22.06 & 46.56 & 62.28 \\
\hline Rupees) & $3001-6000$ & 40.36 & 12.7 & 15.79 \\
\hline & $>6000$ & 34.15 & 4.23 & 3.51 \\
\hline & Mean Monthly Income & 6077.68 & 1364.95 & 1487.86 \\
\hline
\end{tabular}


182 Sugata Hazra et al.

Table 9.2 (Continued)

\begin{tabular}{cllll}
\hline Characteristics & $\begin{array}{l}\text { Men Headed } \\
\text { Households } \\
(\%)\end{array}$ & $\begin{array}{l}\text { Women } \\
\text { Headed } \\
\text { Households } \\
(\%)\end{array}$ & $\begin{array}{l}\text { Widow } \\
\text { Headed } \\
\text { Households } \\
(\%)\end{array}$ \\
\hline $\begin{array}{c}\text { House Area } \\
\text { (Square }\end{array}$ & $<50$ & 37.29 & 44.97 & 39.47 \\
Metres) & $50-100$ & 37.04 & 31.75 & 32.46 \\
& $>100$ & 25.76 & 23.28 & 28.07 \\
Farm Size & Own House & 96 & 93.12 & 92.98 \\
(Hectares) & 0 & 28.92 & 31.22 & 78.07 \\
& $0.01-1.00$ & 58.58 & 60.85 & 14.91 \\
Total Observations & $1.00+$ & 12.5 & 7.94 & 7.02 \\
\end{tabular}

Source: Primary survey, 2017.

than half the widows were illiterate and 32.46 per cent had studied up to the end of primary education.

In the present study, the economic characteristics of the households included main livelihood, monthly income, house area, farm size and ownership. Low literacy and income are linked, hence a huge disparity in monthly income is observed between men- and women-headed households. Men respondents were mostly farmers and fishermen (36.1 per cent) and construction and factory workers (21.6 per cent), whereas women (including widow-headed household respondents) were mainly unpaid home carers, given their household care tasks and restrictions on mobility. The mean monthly income of the men heads is Rs. 6078, whereas it is only Rs. 1365 for women heads (1 Indian rupee $=0.014$ US\$, Sept. 2019). More widow-headed households (62 per cent) had income which was lower (earning less than Rs. 3000) than women-headed households (47 per cent). In contrast, not even 1 per cent of men stayed at home as unpaid carers, and only 3.4 per cent were without income.

The majority of the respondents do own houses, but small ones (less than $50 \mathrm{~m}^{2}$ in area). Almost 30 per cent of total respondents have no farm land. More widow-headed households managed to own their home than women-headed households, which could be due to government housing schemes for poor women. Most did not, however, have their own farm land, and in the absence of an alternate livelihood option in the region, male migration is common.

\section{Vulnerability and women-headed households}

Recent research in climate change has indicated that vulnerabilities are gendered and women are typically portrayed as vulnerable, rather than as negotiating and dealing regularly with different kinds of changes in their 
lives (Okali and Naess 2013; Rao et al. 2019). A vulnerability assessment helps us to know whether women-headed households are more vulnerable than their men-headed counterparts. Both bio-physical and socio-economic vulnerabilities have been assessed in this study. Bio-physical vulnerability is a function of the frequency and severity of climatic hazards, while social vulnerability is the inherent property of a system arising from its internal characteristics (Brooks et al. 2005). 28 theoretically important and policyrelevant bio-physical and socio-economic variables (sub-components) were selected under five major components - climate variability, environmental stressors, impact of extreme events, socio-demographic profile and economic status. The bio-physical variables are perceptions of respondents, whereas the socio-economic variables are responses that are tangible and measurable. ${ }^{12}$ All the responses are in percentages and have a positive $(+)$ functional relationship with major components of vulnerability, which means the higher the value, the higher the vulnerability. A description of the variables used in the present study is provided in Table 9.3.

In the bio-physical vulnerability index (BPVI) assessment survey, respondents stated that there had been a change in precipitation and an increase in temperature over the previous five years, but the perception was slightly higher in the women-headed households than in the men-headed ones. More than 50 per cent of respondents (all men-, women- and widow-headed households) reported experiences of environmental stressors (flood, cyclone and erosion) with increasing frequency and impact in the last 10 years. These extreme events directly caused livelihood shocks. The survey data indicate that the women- and widow-headed households reported more monetary losses as well as loss of life than men-headed households in extreme events, due to crop failure, and livestock and equipment damage (Table 9.2).

Similarly, for the socio-economic vulnerability index (SEVI) assessment, survey data reveal that most of the women-headed households are socially vulnerable, and the percentage of young and elderly illiterate members is also higher than in the men-headed households. Elderly people and children are dependents, have mobility constraints and lack resilience. Lower education or illiteracy constrains their ability to understand warning information and access to recovery information. The presence of widows/divorcees or separated women is substantially higher in the women-headed households. All these factors make women-headed households more sensitive and susceptible to extreme environmental events. It is observed that most of the women heads have no income or savings, and work as unpaid home carers. The existence of a large number of non-workers in both men- and women-headed households contributes to a slower recovery from any hazard event, whether of fast or slow onset. Lower resilience or adaptive capacity is often characterised by unsafe drinking water, poor sanitation facilities and the predominance of "kutcha" houses (thatched houses with roofs made of hay/leaves/branches/ jute bags/plastic or other materials) - conditions which are typical for women-headed households. Food insecurity is a high risk; eating one meal a day was 
Table 9.3 Vulnerability Assessment of Men and Women Headed Households in MD

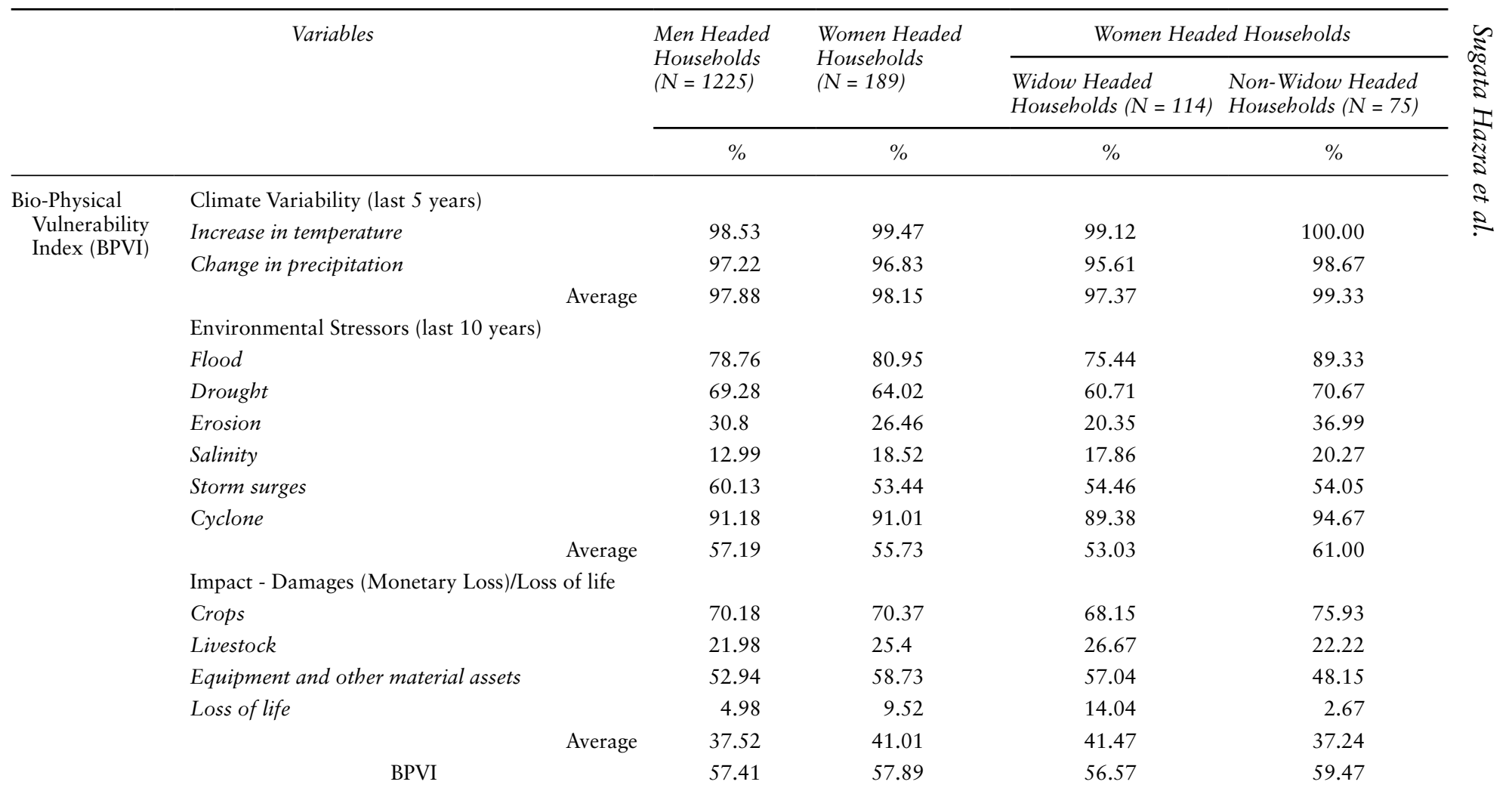




\begin{tabular}{|c|c|c|c|c|c|}
\hline \multirow{21}{*}{$\begin{array}{r}\text { Socio-Economi } \\
\text { Vulnerability } \\
\text { Index (SEVI) }\end{array}$} & \multicolumn{5}{|l|}{ Socio-Demographic Profile } \\
\hline & Household size $(\geq 5)$ & 50.65 & 39.15 & 40.74 & 35.19 \\
\hline & Female members (> 50\%) & 27.7 & 47.62 & 54.07 & 31.48 \\
\hline & Aged person $(60+$ years) $(>20 \%)$ & 21.49 & 24.34 & 27.41 & 16.67 \\
\hline & Children $(<15$ years) (> 30\%) & 31.78 & 33.86 & 30.37 & 42.59 \\
\hline & Widow/Divorced/Separated (> 10\%) & 15.11 & 69.31 & & \\
\hline & Illiteracy $(>30 \%)$ & 26.06 & 37.57 & 42.22 & 25.93 \\
\hline & Socially backward class (SC, ST, OBC) & 65.77 & 66.67 & 65.19 & 70.37 \\
\hline & Chronically ill-injured-disabled & 74.75 & 73.02 & 72.59 & 75.93 \\
\hline & Average & 39.16 & 48.94 & 47.51 & 42.59 \\
\hline & \multicolumn{5}{|l|}{ Economic Status } \\
\hline & Agricultural dependency ( $\geq 50 \%)$ & 38.4 & 12.17 & 11.85 & 14.81 \\
\hline & Household head without income & 3.51 & 36.51 & 22.96 & 70.37 \\
\hline & Non-workers (>50\%) & 34.07 & 35.45 & 36.30 & 33.33 \\
\hline & Food insecurity (eaten 1 meal per day or less) & 42.81 & 43.39 & 42.96 & 44.44 \\
\hline & Roof (other than cement, brick, asbestos) & 30.07 & 40.74 & 45.19 & 48.15 \\
\hline & Unsafe drinking water (pond, canal, spring, etc.) & 7.92 & 7.41 & 8.89 & 3.70 \\
\hline & No sanitation facility & 62.66 & 64.02 & 63.70 & 68.52 \\
\hline & No support from NGO or Govt. & 72.71 & 69.84 & 69.63 & 70.37 \\
\hline & Average & 36.52 & 38.69 & 37.69 & 44.21 \\
\hline & SEVI & 37.84 & 43.82 & 42.27 & 43.46 \\
\hline
\end{tabular}




\section{Sugata Hazra et al.}

reported more by the adult women in women-headed households than in widow-headed ones, who had fewer household members. There is high pressure of work on women who are carers in all three types of household due to a high incidence of chronic illness or disability in the family. The survey reported that over the last five years, almost 70 per cent of households had not received any assistance from the government or NGOs for improvement of their home (wall, roof and floor) or livelihood diversification. The insecurity resulting from poor access to food is heightened for women-headed households by a combination of malnutrition, inadequate sanitation and the inability to pay for health services due to low or no income.

The chapter has developed a composite vulnerability index (CVI) which combines the bio-physical and socio-economic vulnerability indices. Results show that the BPVI values are similar for men- and women-headed households, which indicates that they are bio-physically in the same vulnerable situation. The SEVI value of women-headed households (43.8 per cent) is much higher than that of men-headed households ( 37.8 per cent). It can be said that women-headed households are socio-economically in more vulnerable situations than men-headed households in MD. The value of the CVI as derived in the present chapter is greater for the women-headed households ( 50.9 per cent) than the men-headed households ( 47.6 per cent) and widow-headed households (49.4 per cent). The lower CVI of widowed households can be explained by their lower dependency ratio, alongside lower dependence on agriculture (Figure 9.3). The ability of women-headed households to absorb losses and be resilient to environmental impacts is very low. Due to their low work participation and income, and significant family care responsibilities, women heads have a more difficult time with recovery than men. The data show that overall, widow-headed households are vulnerable, but sustain themselves as they get support, while women-headed households without support or pensions remain highly vulnerable.

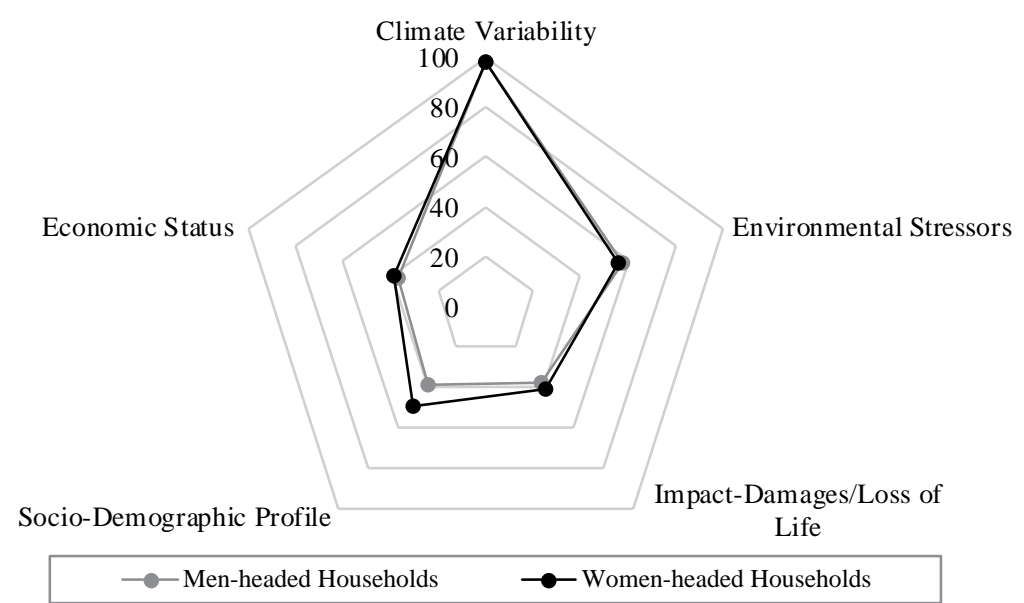

Figure 9.3 Major components in vulnerability assessment. 


\section{Migration and women-headed households}

Migration is one of the options which human populations use to adapt to environmental changes (McLeman and Hunter 2010). It can potentially reduce the socio-economic and bio-physical vulnerabilities of women-headed households. As stated earlier, among the 1414 households who participated in the household survey, 22 per cent have sent migrants, and the percentage of migrant-sending households was high in the 'very high' and 'high' multi-hazard zones of the delta (Figure 9.4), indicating that people are moving from vulnerable parts of the MD to live and work in safer places.

Out of the total 189 women-headed households, 82 (43.4 per cent) are with migrants and 107 (56.6 per cent) are without migrants. A significant number of women household heads have acquired their present status because of the out-migration of men, making it imperative to discuss whether migration reduces or aggravates the vulnerability of women-headed households.

Seasonal migration (56.58 per cent) dominates the migration pattern among women-headed households (Table 9.4). From women-headed households, men (74.85 per cent) mostly migrate once or twice a year leaving the women behind to take on the additional responsibilities of dependents and households. Women migrants from women-headed households are 25.15 per cent, mostly students, unpaid home carers or unemployed.

Both men and women migrants with secondary education and in the age group 21-40 migrate more from women-headed households. In case of women migrants, the decision to migrate depends on the household. They mostly move with their family. It is the elderly people, children and women who stay behind as the 'trapped population' in the delta. With diminishing returns from traditional agriculture and fisheries in the face of climatic

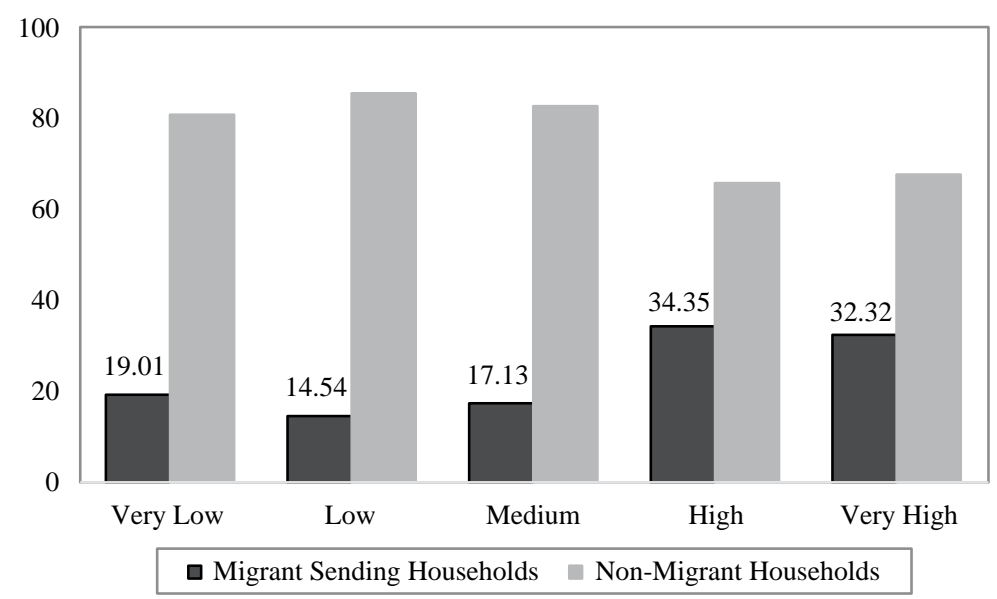

Figure 9.4 Distribution of households in five multi-hazard zones. 


\section{Sugata Hazra et al.}

Table 9.4 Patterns of Migration from Women Headed Households in MD $(N=189)$

\begin{tabular}{|c|c|c|c|}
\hline \multicolumn{3}{|l|}{ Responses } & \multirow{2}{*}{$\begin{array}{c}\% \\
56.58\end{array}$} \\
\hline Type & & Seasonal migration & \\
\hline Frequency & & 1-2 times & 45.9 \\
\hline Duration & & 3-6 months & 37.1 \\
\hline Scale & & Internal Migration & 98.68 \\
\hline \multirow[t]{3}{*}{ Destinations } & State & $\begin{array}{c}\text { Odisha, West Bengal, } \\
\text { Karnataka, Delhi }\end{array}$ & 69.74 \\
\hline & District & Khordha, Kolkata, Puri & 65.12 \\
\hline & City & $\begin{array}{l}\text { Bhubaneswar, Puri } \\
\text { (M), Jagatsinghpur } \\
\text { (M) }\end{array}$ & 64.81 \\
\hline \multirow{12}{*}{$\begin{array}{l}\text { Current } \\
\text { Migrant's } \\
\text { Characteristics }\end{array}$} & Male Migrants & & 74.85 \\
\hline & Age & $21-40$ & 54.92 \\
\hline & Marital Status & Currently Married & 59.02 \\
\hline & Education & Secondary & 47.41 \\
\hline & Livelibood & $\begin{array}{l}\text { Factory Worker, } \\
\text { Regular Salaried } \\
\text { Employee, } \\
\text { Construction Worker }\end{array}$ & 77.88 \\
\hline & Monthly Income & Rs. 10000 and Below & 70.87 \\
\hline & Female Migrants & & 25.15 \\
\hline & Age & $21-40$ & 53.66 \\
\hline & Marital Status & Currently Married & 58.54 \\
\hline & Education & Secondary & 44.74 \\
\hline & Livelibood & $\begin{array}{l}\text { Unpaid Home Carer, } \\
\text { Student, Unemployed }\end{array}$ & 100 \\
\hline & Monthly Income & No Income & 100 \\
\hline \multirow[t]{3}{*}{ Reasons } & First & Seeking employment & 41.78 \\
\hline & Second & Seeking education & 21.23 \\
\hline & Third & $\begin{array}{l}\text { Family obligations / } \\
\text { problems }\end{array}$ & 19.18 \\
\hline \multirow[t]{3}{*}{ Remittances } & Type & Money & 42.11 \\
\hline & Frequency & Monthly & 50 \\
\hline & Amount & Rs. 5000 and Below & 37.84 \\
\hline \multirow[t]{3}{*}{$\begin{array}{l}\text { Uses of } \\
\text { Remittances }\end{array}$} & Rank-1 & $\begin{array}{l}\text { Daily consumption } \\
\text { (food, bills) }\end{array}$ & 73.68 \\
\hline & Rank-2 & Education & 39.29 \\
\hline & Rank-3 & Health care & 40.74 \\
\hline
\end{tabular}

Source: Primary survey, 2017. 
uncertainties, migration is emerging as an alternative livelihood strategy in the MD, according to the respondents.

The immediate reason behind migration is economic (41.78 per cent), with the majority of the men migrating in search of employment opportunities. Friends and family members who have already migrated temporarily provide an information network for migration. The second most frequently mentioned reason is education, with 21 per cent of respondents reporting that the migrant left to study for a degree or to obtain training in a new skill. The survey results also provide evidence of female migration (25.51 per cent) from the delta, though mostly as unaccompanied spouses and home carers.

However, migration often shows a dual and contradictory impact on the vulnerability of the women-headed households. While women left behind due to the out-migration of men constitute a vulnerable group by itself, monthly remittances sent by migrant male members have the potential to alleviate their vulnerable status, at least marginally. The household survey revealed that remittances improve standards of living by enabling them to pay for food, education and health care. Consequently, thanks to remittances, the monthly per-capita expenditure (MPCE) of women-headed households with migrants was higher (Rs. 2355) than that of those without any migrant members (Rs. 1473). Most of the household survey respondents mentioned that migration improves the social and economic status of migrant-sending households. In other words, among women-headed households, those with migrants, mostly men, are better off than those without. More than 85 per cent of total respondents felt migration is helpful for migrants also. All the respondents in the household survey reported that migration improves economic security, education and work opportunities for migrants, and it also brings new ideas and practices to the village when migrants return. Thus, the exchange of money, knowledge and ideas between the migrant's places of origin and destination can potentially reduce the socio-economic and bio-physical vulnerabilities of the women-headed households. Migration, then, has both positive and negative impacts on human development (Figure 9.5a and 9.5b).

While there are several positive outcomes of migration in the women-headed households and the community at large, the respondents felt that it left very few young men in the village, reducing the community's ability to face slow- or fast-onset climatic hazards and adversities. With more than 25 per cent of the surveyed households expressing their intention to migrate in the future, the propensity to migration in the villages of MD will increase in future, leaving more women-headed households behind to cope with and adapt in situ to climate change and climatic disasters. The social vulnerability of women-headed households, both with and without migrants, requires consideration and has implications for policy support. 

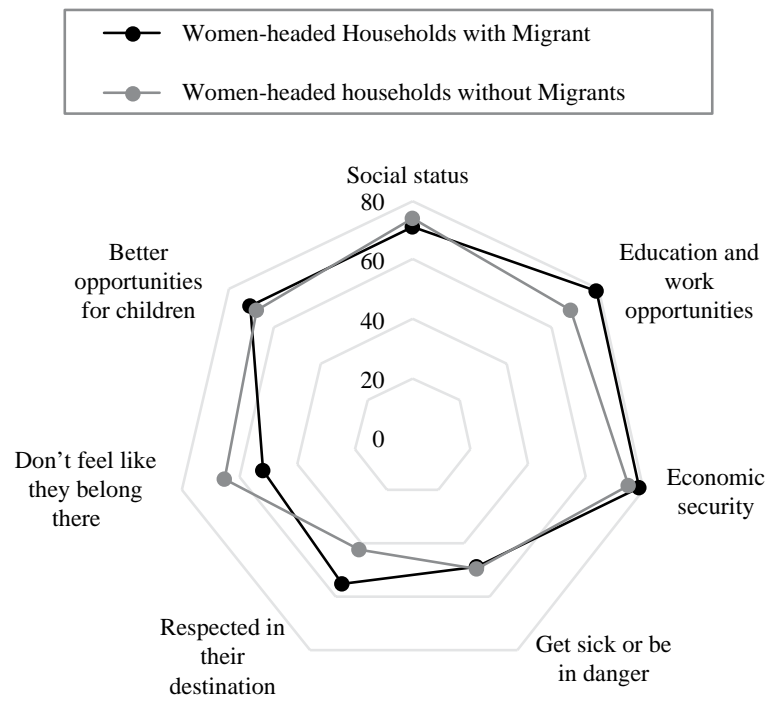

Figure 9.5a Dimensions of migration at individual level (migrant).

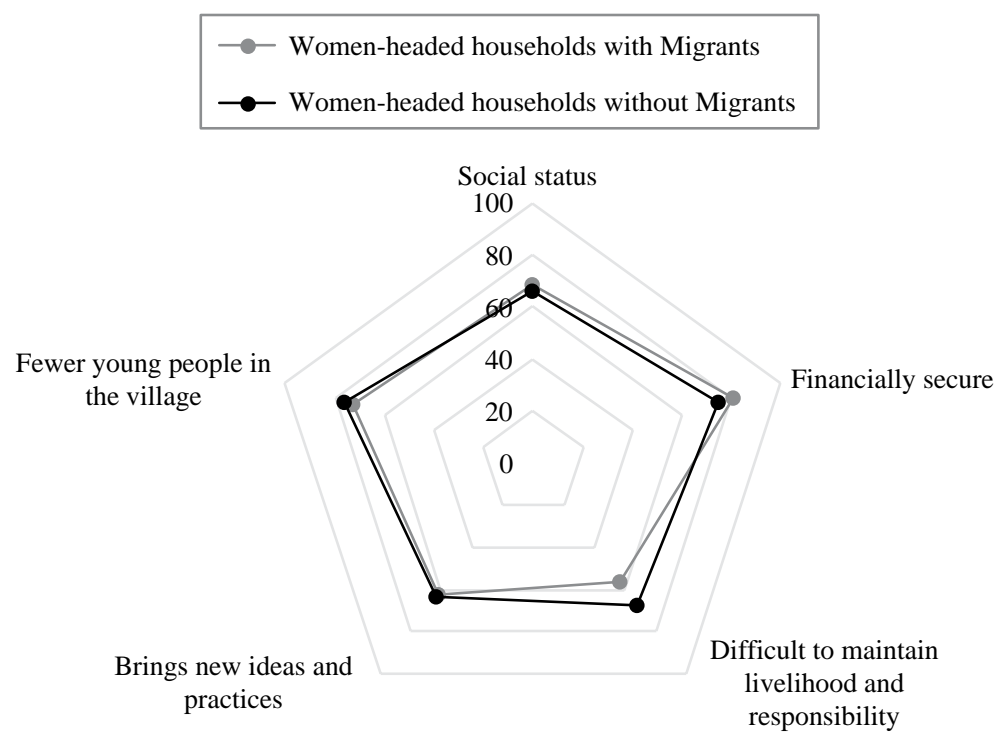

Figure 9.5b Dimensions of migration at collective level (household and village).

\section{Adaptation and women-headed households}

Adaptation experiences are gendered and even though exposure to climate variations may be the same for men and women in any given location, there are gender-based differences in vulnerability and consequently in adaptation and adaptive capacity (Adger et al. 2005; Muttarak et al. 2015). It has 
been observed, for instance, that men and women farmers in many developing countries have different levels of vulnerability and adaptive capacity to climate change (Denton 2002). In the fifth IPCC assessment report, adaptation is described as the "process of adjustment to actual or expected climate and its effects" (IPCC 2014:39). Though not gendered, it is apparent that adaptation, in IPCC terms, is an intervention to adjust to climate change effects.

At the local level, the Odisha 2010-15 Climate Change Action Plan (OCCAP) recognized the impact of climate change on women in the context of water scarcity and reducing availability of biomass, but did not address the issue of adaptation (Government of Odisha 2010-2015). In relation to the key issues of adaptation to coastal disaster, water stress, declining agriculture and health, women's perspectives were hardly discussed. The adaptation activities included in the action plan are neither drawn from women's needs nor specify any. The survey sought the views of the women respondents with regard to 21 adaptation activities, of which agriculture-related adaptation activities were asked only for relevant households (Table 9.5). The recall period was the previous five years (2011-16).

The assumption that migration is positive would mean that womenheaded household gain from migration. Adopting this intersectional approach, the women-headed households with and without migrants were asked in the survey about adaptation activities and whether they were better off after taking up the said activity. Success was calculated based on whether the household had improved by taking up the particular adaptation activity. The activities shown in Table 9.5 were related to increase in livelihood, capacity building and building infrastructure.

Table 9.5 shows that both types of households - women-headed with and without migrants - succeeded equally in some activities, such as taking loans, using hired labour and higher amounts of fertilizer, going outside to work, sending a household member to work outside and receiving assistance from NGOs and government. With future safety as a strategy in this disaster-prone area in mind, both planted trees around the house, though more women without migrants did so, moved house and stayed with the community. New gender roles were also noticed in households without migrants, as women have taken up male-oriented activities such as hiring labour and carrying out irrigation work.

Households with migrants were highly successful in crop diversification and using irrigation. They adapted and in an attempt to make the situation better made use of insurance and joined cooperatives. These were related to their livelihood and were enabled as in all the households, migrant members returned. Together both types of household successfully used adaptation activities such as crop diversification, climate-tolerant crops, tree plantations around the home, protection against natural hazards (own organized/ community shelter). These activities improved household finances, education, health and access to government or NGO assistance. 


\section{Sugata Hazra et al.}

Table 9.5 Adaptation Activities of Women Headed Households in the last 5 years

\begin{tabular}{|c|c|c|c|c|c|c|c|}
\hline \multirow{2}{*}{\multicolumn{2}{|c|}{ Adaptation Activities }} & \multicolumn{2}{|c|}{$\begin{array}{l}\text { Women Headed } \\
\text { Households with } \\
\text { Migrants }(N=82)\end{array}$} & \multicolumn{2}{|c|}{$\begin{array}{l}\text { Women Headed } \\
\text { Households } \\
\text { without Migrants } \\
(\mathrm{N}=107)\end{array}$} & \multicolumn{2}{|c|}{ Total $(N=189)$} \\
\hline & & Yes (\%) & $\begin{array}{l}\text { Success } \\
(\%)\end{array}$ & Yes $(\%)$ & $\begin{array}{l}\text { Success } \\
(\%)\end{array}$ & $\begin{array}{l}\text { Yes } \\
(\%)\end{array}$ & $\begin{array}{l}\text { Success } \\
(\%)\end{array}$ \\
\hline 1 & $\begin{array}{l}\text { Loan to purchase } \\
\text { things for the } \\
\text { household, or } \\
\text { to improve } \\
\text { livelihood }\end{array}$ & 42.68 & 54.29 & 27.1 & 58.62 & 33.86 & 56.25 \\
\hline 2 & $\begin{array}{l}\text { Insurance } \\
\text { for main } \\
\text { livelihood }\end{array}$ & 17.07 & 92.86 & 12.15 & 53.85 & 14.29 & 74.07 \\
\hline 3 & $\begin{array}{l}\text { Joined a } \\
\text { cooperative } \\
\text { in relation } \\
\text { to main } \\
\text { livelihood }\end{array}$ & 20.73 & 76.47 & 16.82 & 66.67 & 18.52 & 71.43 \\
\hline 4 & $\begin{array}{l}\text { Modified, or } \\
\text { improved } \\
\text { House (walls, } \\
\text { roof, floor) }\end{array}$ & 39.02 & 65.63 & 34.58 & 75.68 & 36.51 & 71.01 \\
\hline 5 & $\begin{array}{l}\text { Cut down trees } \\
\text { around home }\end{array}$ & 13.41 & 54.55 & 12.15 & 53.85 & 12.7 & 54.17 \\
\hline 6 & $\begin{array}{l}\text { Planted trees } \\
\text { around home }\end{array}$ & 25.61 & 95.24 & 33.64 & 72.22 & 30.16 & 80.7 \\
\hline 7 & $\begin{array}{l}\text { Using hired } \\
\text { labour to } \\
\text { support in } \\
\text { generating } \\
\text { income }\end{array}$ & 15.85 & 69.23 & 9.35 & 70 & 12.17 & 69.57 \\
\hline 8 & $\begin{array}{l}\text { Women working } \\
\text { outside the } \\
\text { village }\end{array}$ & 3.66 & 66.67 & 14.95 & 68.75 & 10.05 & 68.42 \\
\hline 9 & $\begin{array}{l}\text { Moved to a new } \\
\text { house within } \\
\text { the same } \\
\text { village }\end{array}$ & 3.66 & 100 & 3.74 & 75 & 3.7 & 85.71 \\
\hline 10 & $\begin{array}{l}\text { Sent a household } \\
\text { member to } \\
\text { work outside } \\
\text { the village }\end{array}$ & 58.54 & 68.75 & 14.02 & 66.67 & 33.33 & 68.25 \\
\hline 11 & $\begin{array}{l}\text { Household } \\
\text { member } \\
\text { come back } \\
\text { permanently }\end{array}$ & 25 & 100 & 0 & 0 & 12.5 & 100 \\
\hline
\end{tabular}


Table 9.5 (Continued)

\begin{tabular}{|c|c|c|c|c|c|c|c|}
\hline \multicolumn{2}{|c|}{ Adaptation Activities } & \multicolumn{2}{|c|}{$\begin{array}{l}\text { Women Headed } \\
\text { Households with } \\
\text { Migrants }(N=82)\end{array}$} & \multicolumn{2}{|c|}{$\begin{array}{l}\text { Women Headed } \\
\text { Households } \\
\text { without Migrants } \\
(N=107)\end{array}$} & \multicolumn{2}{|c|}{ Total $(N=189)$} \\
\hline & & Yes (\%) & $\begin{array}{l}\text { Success } \\
(\%)\end{array}$ & Yes $(\%)$ & $\begin{array}{l}\text { Success } \\
(\%)\end{array}$ & $\begin{array}{l}\text { Yes } \\
(\%)\end{array}$ & $\begin{array}{l}\text { Success } \\
(\%)\end{array}$ \\
\hline 12 & $\begin{array}{l}\text { Crop } \\
\text { diversification }\end{array}$ & 16.67 & 100 & 0 & 0 & 5.56 & 100 \\
\hline 13 & $\begin{array}{l}\text { Planting climate } \\
\text { tolerant crops }\end{array}$ & 0 & 0 & 8.33 & 100 & 5.56 & 100 \\
\hline 14 & $\begin{array}{l}\text { Increased used of } \\
\text { fertiliser }\end{array}$ & 50 & 66.67 & 66.67 & 62.5 & 61.11 & 63.64 \\
\hline 15 & Put in irrigation & 33.33 & 100 & 33.33 & 50 & 33.33 & 66.67 \\
\hline 16 & $\begin{array}{l}\text { Mixed farming/ } \\
\text { fishing } \\
\text { production }\end{array}$ & 22.22 & 0 & 0 & 0 & 8.7 & 0 \\
\hline 17 & $\begin{array}{l}\text { Bought farming } \\
\text { / fishing } \\
\text { equipment }\end{array}$ & 0 & 0 & 0 & 0 & 0 & 0 \\
\hline 18 & $\begin{array}{l}\text { Training on } \\
\text { new fishing or } \\
\text { farming skills/ } \\
\text { methods }\end{array}$ & 0 & 0 & 0 & 0 & 0 & 0 \\
\hline 19 & $\begin{array}{l}\text { Fished new } \\
\text { breeds / used } \\
\text { new breeds in } \\
\text { ponds }\end{array}$ & 0 & 0 & 0 & 0 & 0 & 0 \\
\hline 20 & $\begin{array}{l}\text { Received } \\
\text { government } \\
\text { or NGO } \\
\text { assistance }\end{array}$ & 25.61 & 80.95 & 24.3 & 84.62 & 24.87 & 82.98 \\
\hline 21 & $\begin{array}{l}\text { Organised own } \\
\text { protection } \\
\text { or used a } \\
\text { community } \\
\text { shelter }\end{array}$ & 25.61 & 61.9 & 26.17 & 85.71 & 25.93 & 75.51 \\
\hline \multicolumn{2}{|c|}{ Average } & 20.89 & 59.68 & 16.06 & 49.72 & 18.23 & 61.35 \\
\hline
\end{tabular}

Source: Primary survey, 2017.

The average success percentage (all adaptation activities) for women-headed households with migrants was 59.67, higher than for those without migrants, which indicates that migration has the potential to reduce the overall vulnerability of women-headed households by enhancing their adaptive capacity and agency to address climate variability. This view is strengthened by their strong advocacy of working outside the village for both men and women. 
Activities which require more time, money and labour are mostly adopted by women-headed households with migrants. The perception that women are agency-less is eliminated, as an important gendered role adoption is visible. This is an attempt at breaking barriers, though it must be recognized that women's mobility remains restricted and patriarchy remains in place (Figure 9.4), with women migrating from this region not for economic reasons but as carers of families.

\section{Conclusion: women-headed households in climate change}

While it is widely accepted that climate change may promote migration from coastal areas in the world as well as in India, this study was able to establish a relationship between high risk of climate hazards and higher migration in the deltaic region of Odisha. The primary survey of 1414 households also confirmed a similar trend in the temporary or short-term migration of men, resulting in an increasing number of women-headed households. This gender-disaggregated data set, the first of its kind for the $\mathrm{MD}$, has given rise to certain observations which have significant implications for future research as well as policy interventions. The bio-physical and socio-economic vulnerability indices, as well as the composite vulnerability index, give an in-depth understanding of the vulnerability of women-headed households in the context of climatic changes. The status of widows and their vulnerabilities and strengths have also been analyzed in the chapter.

An important point learnt from the study is that both women- and widow-headed households are more vulnerable to the impacts of climate change in the delta than households headed by men, mainly for socio-economic reasons. However, an important conclusion that the study draws from a household perspective is the lower vulnerability of widow-headed households than women-headed households, as the latter have less support and no steady income.

The risks faced by women- and widow-headed households due to their household responsibilities as unpaid carers and their inability to access income keep them poor. With non-existent policy initiatives, -no farm skill development in the sending areas, limited access to land and no insurance cover, they remain deprived of their economic rights. Feminization of poverty in women-headed households is not a new phenomenon, but it has not been a national or international target for eradication, even when women remain food insecure and unpaid carers, as seen in this study.

Second, in spite of their high vulnerability for socio-economic reasons, it has been highlighted that women-headed households do take on male roles when it comes to adaptation activities. Though it is a positive attribute, we have to take into account the increase in pressure of work on these women. Since they are the main carers of children, larger numbers of women in the household and chronically ill or disabled members of the family, and they live in a patriarchal system where men rarely do domestic work, the gender bias in which masculine privilege prevails continues in post-climatic 
hazard situations. This can give them less time to socially network which they need not only for a better quality of life but also to access socially derived resources. It may also restrict women's personal savings which can be used in emergencies or for personal/children's needs. These are markers of vulnerability that are hidden in research or in the strategies adopted for overcoming them.

Women-headed households remain highly vulnerable in climate change situations as the impact of adaptation has not improved their overall situation. Successful adaptations identified include crop diversification and farming practices, but in-situ adaptation has not succeeded, resulting in migration. Women-headed households have thus supported the idea of migration, but restricted mobility has been a barrier that has not been overcome until recently, when younger women are found to be migrating. It can be concluded from the study that women-headed households with migrants, if managed and monitored properly, have the potential to alleviate their vulnerability. Remittances received regularly or intermittently by both women and women-headed households partially meet their everyday needs and reduce their economic vulnerability to some extent. However, as there is no effective policy for internal migrants in the country, these remittances remain largely uncertain for the women-headed households left behind.

In conclusion, the important idea that the chapter draws from a household perspective on the feminization of poverty is the change for extremely deprived widow-headed households who, with economic support, increase their ability to rise from the low level on which society places them. Here, social change due to the transformation of gender roles also signifies a more gender-equitable role in the context of women-headed households in general, as they do take on male roles in adaptation which, though not economically viable, does entail social change. It cannot also be overlooked that men may also be affected, due to their inability to pay for health services and clean sanitation, especially in migrant destinations. This element of powerlessness and stress for men needs further exploration.

\section{Notes}

1 Head of the household: She or he is generally the person who bears the chief responsibility for managing the affairs of the household and takes decision on behalf of the household. The head of household need not necessarily be the oldest male member or an earning member, but may be a female or a younger member of either sex. In case of an absentee de jure 'Head' who is not eligible to be enumerated in the household, the person on whom the responsibility of managing the affairs of household rests was to be regarded as the head irrespective whether the person is male or female (Government of India data. Key words).

2 Calculated from Table HH-06 Households By Marital Status, Sex and Age of the Head of Household, Household Series, Census of India, 2011a.

3 National Family Health Survey (NFHS) publishes data on headship based on self-reported survey.

4 According to the Government of India census SECC 2011, if any female member of a household desires or declares herself as a separate household, she is treated as a separate household (Govt of India SECC 2011b). 


\section{Sugata Hazra et al.}

5 India's National Action Plan on Climate Change (NAPCC) states, "the impacts of climate change could prove particularly severe for women. With climate change, there would be increasing scarcity of water, reductions in yields of forest biomass, and increased risks to human health with children, women and the elderly in a household becoming the most vulnerable, special attention should be paid to the aspects of gender" (Government of India, 2008: 14)

6 DECCMA project explores whether migration is an adaptation option in such low-lying deltaic regions and aims to provide policy support to create conditions for sustainable gender sensitive adaptation (DECCMA Brief, 2017, www.deccma.com). Study sites include the Ganges-Brahmaputra-Meghna Delta in Bangladesh and India, Mahanadi Delta in India and Volta Delta in Ghana (www. cariaa.net).

7 The state female literacy rate is 64.01 per cent as per the 2011 Census (Government of India, 2011a).

8 The participants in the stakeholder workshops in Bhadrak and Puri districts under the DECCMA project work in the MD made this observation.

9 A migrant-sending household is any household that has members that have migrated from the sending area in the last 10 years. This includes current migrants and returned migrants as per the DECCMA's household survey methodology.

10 Non-migrant-sending households are those which have no members who have migrated from the sending area in the last 10 years as per the DECCMA's household survey methodology.

11 The following definitions are used in the DCCMA household survey methodology: Women-Headed Household: Women-headed households are those in which an adult female has the most authority and responsibility for household affairs or earns the most income in the household. Male-Headed Household: Maleheaded households are those in which an adult male has the most authority and responsibility for household affairs or earns the most income in the household. If the household head has migrated away, then the head is the person who has the most influence over household affairs in their absence, or who earns the most income.

12 The indices on bio-physical and socio-economic vulnerability are based on indicators by which the respondents provided their perception in the survey questionnaire.

\section{References}

Adger, W.N., N. Brooks, G. Bentham, M. Agnew and S. Eriksen. 2005. New Indicators of Vulnerability and Adaptive Capacity. Norwich: Tyndall Centre for Climate Change Research.

Afifi, T., A. Milan, B. Etzold, B. Schraven, C. Rademacher-Schulz, P. Sakdapolrak, A. Reif, K. Geest and K. Warner. 2016. 'Human Mobility in Response to Rainfall Variability: Opportunities for Migration as a Successful Adaptation Strategy in Eight Case Studies', Migration and Development, 5(2): 254-274. doi:10.1080/21 632324.2015.1022974

Agarwal, B. 1994. A Field of One's Own: Gender and Land Rights in South Asia. Cambridge South Asian Studies. Cambridge: Cambridge University Press.

Alhassan, S., J. Kuwornu and Y. Osei-Asare. 2019. 'Gender Dimension of Vulnerability to Climate Change and Variability: Empirical Evidence of Smallholder Farming Households in Ghana', International Journal of Climate Change Strategies and Management, 11(2): 195-214. https://doi.org/10.1108/IJCCSM-10-2016-0156. Accessed 20 October 2019. 
Arora-Jonson, S. 2011. 'Virtue and Vulnerability: Discourses on Women, Gender and Climate Change', Global Environmental Change, 21: 744-751.

Brooks, N., W.N. Adger and P.M. Kelly. 2005. 'The Determinants of Vulnerability and Adaptive Capacity at the National Level and the Implications for Adaptation', Global Environmental Change, 15(2): 151-163.

Buvinić, M. and G.R. Gupta. 1997. 'Female-headed Households and FemaleMaintained Families: Are They Worth Targeting to Reduce Poverty in Developing Countries?', Economic Development and Cultural Change, 45(2): 259-280.

Chant, S. 2003. 'Female Household Headship and the Feminisation of Poverty: Facts, Fictions and Forward Strategies.' New Working Paper Series (9). Gender Institute, London School of Economics and Political Science, London, UK.

Chant, S. 2015. 'Female Headed Households Leadership as an Asset? Interrogating the Intersections of Urbanization, Gender, and Domestic Transformation', in Caroline Masor (ed.) Gender, Asset Accumulation and Just Cities. Routledge, pp. 33-51.

Chen, M.A. (ed.) 1998. Widows in India: Social Neglect and Public Action. New Delhi: Sage.

Das, S., S. Hazra, T. Ghosh, S. Hazra and A. Ghosh. 2016. 'Migration as an Adaptation to Climate Change in Mahanadi Delta', Abstract Number: ABSSUB-98. Paper presented at the Conference 'Adaptation Future 2016', Rotterdam, Netherlands, 10-13 May.

Denton, F. 2002. 'Climate Change Vulnerability, Impacts, and Adaptation: Why Does Gender Matter?', Gender and Development, 10(2): 10-20.

Desai, S. and M. Banerji. 2008. 'Negotiated Identities: Male Migration and LeftBehind Behind Wives in India', Journal of Population Research, 25: 490-499.

Doocy, S., A. Daniels, S. Murray and T.D. Kirsch. 2013. 'The Human Impact of Floods: A Historical Review of Events 1980-2009 and Systematic Literature Review', PLOS Currents Disaster, 16 April. https://pdfs.semanticscholar.org/1251/3c8b56b6434cb1eeea46e0cfa9539ac085e1.pdf?_ga=2.95288660.93114147.15609414611709343239.1560941461. Accessed 19 June 2019.

Duncan, J., E. Tompkins, J. Dash and B. Tripathy. 2017. 'Resilience to Hazards: Rice Farmers in the Mahanadi Delta, India.' Ecology and Society, 22(4): 3. https://doi. org/10.5751/ES-09559-220403. Accessed 10 September 2019.

Gangopadhyay, S. and W. Wadhwa. 2004. Are Indian Female-headed Households more Vulnerable to Poverty? New Delhi: Bazaar Chintan.

Government of India. 2008. National Action Plan on Climate Change, Prime Minister's Council on Climate Change, Ministry of Environment, Forests and Climate Change. http://www.moef.nic.in/modules/about-the-ministry/CCD/ NAP_E.pdf. Accessed 22 June 2017.

Government of India. 2011a. Census of India. Office of the Registrar General and Census Commissioner, Government of India.

Government of India. 2011b. Census of India. Office of the Registrar General and Census Commissioner, Government of India. http://www.censusindia.gov. in/2011census/Hlo-series/HH06.html. Accessed 2 September 2018.

Government of India. SECC 2011a. Socio Economic and Caste Census (SECC). New Delhi: Ministry of Rural Development, Government of India. http://secc. gov.in/categorywiseIncomeSlabReport?reportType=Female percent 20 Headed percent20Category. Accessed 2 September 2018.

Government of India. SECC 2011b. Socio Economic and Caste Census (SECC). New Delhi: Ministry of Rural Development, Government of India. http://secc. gov.in/faqReportlist. Accessed 1 September 2018. 


\section{Sugata Hazra et al.}

Government of India data. Key words. https://data.gov.in/keywords/female-headed-household. Accessed 1 September 2018.

Government of Odisha. 2013. Annual Report on Natural Calamities (20122013). Bhubaneswar: Special Relief Commissioner, Revenue and Disaster Management Department. http://srcodisha.nic.in/annualReport/fuxOK3oyAnnual_Report_2012-13\%20on\%20NC.pdf. Accessed 10 September 2019.

Government of Odisha. 2014-2015. Odisha Economic Survey. Bhubaneswar: Planning \& Coordination Department, Directorate of Economics and Statistics. http://www.indiaenvironmentportal.org.in/files/file/Odisha \%20Economic_ Survey_2014-15.pdf. Accessed 10 September 2019.

Government of Odisha. 2010-2015. Climate Change Action Plan (OCCAP). Bhubaneswar: Department of Forest and Environment. https://forest.odisha.gov.in/ ActionPlan/CCAP\%20ORISSA\%20FINAL-1.pdf. Accessed 10 September 2018.

Government of Orissa. 2004. Human Development Report. Bhubaneswar: Planning and Coordination Department. http://devfocus.in/wp-content/uploads/ 2014/12/human_development_report_2004_orissa_full_report.pdf. Accessed 10 September 2019.

IIPS. 2015-16. National Family Health Survey (NFHS-4), State Fact Sheet Odisha. Mumbai: International Institute for Population Sciences (IIPS). http://rchiips.org/ NFHS/pdf/NFHS4/OR_FactSheet.pdf. Accessed 8 August 2018.

IPCC. 2014. 'Climate Change 2014: Impacts, Adaptation, and Vulnerability. Part A: Global and Sectoral Aspects.' Contribution of Working Group II to Field, C.B., V.R. Barros, D.J. Dokken, K.J. Mach, M.D. Mastrandrea, T.E. Bilir, M. Chatterjee, K.L. Ebi, Y.O. Estrada, R.C. Genova, B. Girma, E.S. Kissel, A.N. Levy, S. MacCracken, P.R. Mastrandrea, and L.L. White (eds) Fifth Assessment Report of the Intergovernmental Panel on Climate Change. Cambridge/New York: Cambridge University Press, pp. 1132-1197.

Iwasaki, S. 2016. 'Linking Disaster Management to Livelihood Security against Tropical Cyclones: A Case Study on Odisha State in India', International Journal of Disaster Risk Reduction, 19: 57-63.

Jata, S.K., M. Nedunchezhiyan and N. Jata. 2011. 'Flood and Risk Management Strategy in Orissa', Orissa Review, September-October: 62-66.

Julka P. and S. Das. 2015. 'Female Headed Households and Poverty: Analysis Using Household Level Data'. Working paper 133. Chennai: Madras Institute of Development Studies (MIDS).

Klasen, S., T. Lechtenfeld and F. Povel. 2015. 'A feminization of Vulnerability? Female headship, poverty, and vulnerability in Thailand and Vietnam', World Development, 71: 36-53.

Kumar, N. and A. Gupta. 2012. 'Female Headed Household in India: Evidence Based Situational Analysis.' Population Association of America Annual Meeting Program, San Francisco.

Kuppannan, P., A. Haileslassie and K. Kakumanu. 2015. 'Climate Change, Gender and Adaptation Strategies in Dryland Systems of South Asia: A Household Level Analysis in Andhra Pradesh, Karnataka and Rajasthan States of India.' Research Report No. 65 ICRISAT Research Program Resilient Dryland System. Retrieved from https://cgspace.cgiar.org/handle/10568/71194, 11 October 2019.

Lazar, A.N., R.J. Nicholls, A. Payo et al. 2015. 'A Method to Assess Migration and Adaptation in Deltas: Preliminary Fast Track Assessment' (No. 107642). DECCMA working paper, Deltas, Vulnerability and Climate Change: Migration and Adaptation, IDRC project. 
Maqsoodi, A. 2015. 'Census Reveals Gloomy Picture of Life in FemaleHeaded Households' 6 July 2015. http://www.livemint.com/Politics/ RjAdjOgWkNMqHGI1DqX8tJ/Census-reveals-gloomy-picture-of-life-infemaleheaded-house.html. Accessed 1 September 2018.

McLeman, R.A. and L.M.Hunter. 2010'Migration in the Context of Vulnerability and Adaptation to Climate Change Insights from Analogues', Wiley Interdisciplinary Reviews: Climate Change, 1(13): 450-461.

Mitra, A. 2018. 'Male Migrants and Women Farmers in Gorakhpur', Economic and Political Weekly, 53(17): 55-62.

Morchain, D. G. Prati, F. Kelsey and L. Ravon 2015. 'What if Gender Became an Essential, Standard Element of Vulnerability Assessments?', Gender and Development, 23(3): 481-496.

Muttarak, R., W. Lutz and L. Jiang. 2015. 'What Can Demographers Contribute to the Study of Vulnerability?', Vienna Yearbook of Population Research, 13: 1-13.

Nabikolo, D., B. Bashaasha, M. Mangheni and J.G.M. Majaliwa.2012.'Determinants of Climate Change Adaptation among Male and Female Headed Farm Households in Eastern Uganda', African Crop Science Journal, 20(2): 203-212.

Nagla, M. 2008. 'Male Migration and Emerging Female Headed Families', Asian Women, 24(1): 1-23.

Needham, H.F., B.D. Keimand and D. Sathiaraj. 2015. 'A Review of Tropical Cyclone-Generated Storm Surges: Global Data Sources, Observations, and Impacts', Reviews of Geophysics, 53(2): 545-591.

Oginni, A., B. Ahonsi, F. Ukwuije. 2013. 'Are Female-Headed Households Typically Poorer than Male-Headed Households in Nigeria?', Journal of Socio-Economics, 45: 132-137.

Okali, C. and L.O. Naess. 2013. 'Making Sense of Gender, Climate Change and Agriculture in Sub-Saharan Africa: Creating Gender Responsive Climate Adaptation Policy.' Future Agricultures Working Paper 57.

Parikh, J.K., D.K. Upadhyay, T. Singh. 2012. 'Gender Perspectives on Climate Change and Human Security in India: An Analysis of National Missions on Change', Cadmus, 1(4): 180-186.

Patra, M., Tripathy, S., and Jena, I. 2013. 'Health hazards by sea cyclones in Odisha, the supercyclone and the Phailin', Odisha Review, 70(4): 30-37.

Pottier, J. 1994. 'Understanding food stress at local levels.' In Food Systems under Stress in Africa. African Canadian Research Cooperation; proceedings of a workshop held in Ottawa, ON, Canada, 7-8 Nov. 1993. Ottawa, ON, Canada: IDRC.

Rahman, M.K., B.K. Paul, A. Curtis and T.W. Schmidlin. 2015. 'Linking Coastal Disasters and Migration: A Case Study of Kutubdia Island, Bangladesh', The Professional Geographer, 67(2): 218-228.

Rao, N. and A. Hans. 2018. 'Gender and Climate Change: Emergent Issues for Research, Policy and Practice', Economic and Political Weekly, 53(17): 35-37.

Rao, N. and A. Mitra. 2013. 'Migration, Representations and Social Relationships: Experiences in Jharkhand Labour to Western Uttar Pradesh', Journal of Development Studies, 49(6): 846-860.

Rao, N., E.T. Lawson, W.N. Raditloaneng, D. Solomon and M.N. Angula. 2019. 'Gendered Vulnerabilities to Climate Change: Insights from the Semi-Arid Regions of Africa and Asia', Climate and Development, 11(1): 1426. doi: 10.1080/17565529.2017.1372266.

Rosenhouse, S. 1989. 'Identifying the Poor: Is Headship a Useful Concept? Living Standards Measurement Study.' Working Paper 58. Washington, DC: The World Bank. 


\section{Sugata Hazra et al.}

Samling, C.L., S. Das and S. Hazra. 2015. 'Migration in the Indian Bengal Delta and the Mahanadi Delta: a review of the literature.' DECCMA Working Paper, Deltas, Vulnerability and Climate Change: Migration and Adaptation, IDRC Project Number 107642. Available online at: www.deccma.com

Singh, C. 2019. 'Migration as a Driver of Changing Household Structures: Implications for Local Livelihoods and Adaptation', Migration and Development, 8(3): 301-319.

Solomon, D. and N. Rao. 2018. 'Wells and Wellbeing: Gender Dimensions of Groundwater Dependence in South India', Economic and Political Weekly, 53: $38-45$.

Swain, U., M. Swain and Sahoo, R. H. 2016.'Experiences of Women with Super Cyclone in CoastalOdisha. Women and Disasters in South Asia', Survival, Security and Development, 99: 111-154.

Unisa, S. and N. Datta. 2005. Female Headship in India: Levels, Differentials and Impact. 25th Conference of IUSSP in July. France. http://www.demoscope.ru/ weekly/knigi/tours_2005/papers/iussp2005s50705.pdf. Accessed 15 September 2019.

Williams, M. 2015. Gender and Climate Change Financing: Coming out of the Margin. London/New York: Routledge.

\section{Annexure 9}

To get a single value of vulnerability from all the above mentioned bio-physical and socio-economic variables, three methodological steps of vulnerability assessment have been followed in this chapter.

First step of the assessment to get the value for each major component using the concept of simple arithmetic mean:

$$
\mathrm{AI}=\sum \mathrm{S}_{\mathrm{i}} / \mathrm{N}
$$

Where, AI is the value of average index (score) for each major component, Si represents the sub-components (i denotes the $\mathrm{i}^{\text {th }}$ sub-components) and $\mathrm{N}$ is the total number of sub-components in each major component.

In second step, the bio-physical and socio-economic vulnerability indexes are determined by using the concept of weighted arithmetic mean:

$$
\mathrm{VI}=\sum\left(\mathrm{W}_{\mathrm{i}} \cdot \mathrm{AI}_{i}\right) / \sum \mathrm{W}_{\mathrm{i}}
$$

Where, VI is Vulnerability Index (both bio-physical and socio-economic), $\mathrm{AI}_{\mathrm{i}}$ is the major component indexed by $\mathrm{i}, \mathrm{Wi}$ is the weight of each major component (number of sub-components).

In final step, Composite Vulnerability Index (CVI) which is the combination of bio-physical and socio-economic vulnerability indexes has been calculated using simple arithmetic mean (Eq. A.1). 